\title{
The Influence of Religious Fundamentalism on the Conflicts in the Post Communistic States in the Balkan Region
}

\author{
Zoran Matevski \\ Institute of Sociology, Faculty of Philosophy, Skopje \\ zmatevski@fzf.ukim.edu.mk \\ and \\ Dushka Matevska \\ Institute Max Van der Shtoel, South East University, Tetovo \\ dmatevska@seeu.edu.mk
}

\begin{abstract}
The strong link between politics and religion can cause societal problems that arise as a consequence of a politicized religion, which leads to confessional homogeneity and ideologized religion, which in turn leads to fanaticism that can escalate to terrorism towards nonbelievers. Religious fundamentalism turns religion into ideology. Religious fundamentalism frequently manifests itself as a partial or complete rejection of modern ideas, like religious tolerance, secularization, and different achievements in science and technology, which for some reason are not in agreement with religious doctrine. Obviously politicized Islam and Islamic fundamentalism has not ignored the Balkan Peninsula, considering the fact that large portions of the population are members of the Islamic faith. A large number of theologists that preach radical Islam in Muslim religious objects and public educational institutions and the fact that no one has control what is being preached to the believers and minors in the frames of primary school education, represents a serious threat to the ethnic and religious tolerance, and the peace and stability in R. Macedonia. This is achieved by the radical or fundamentalist Islam, by pointing towards the differences that are frequently connected to nationalism.
\end{abstract}

Keywords. post conflict society; religious fundamentalism; religious tolerance 


\section{Introduction}

Religion can mobilize societal groups with a desire to acquire power and influence in the globalized society in which they feel marginalized or think that the globalized society presents a threat to them. This is why the crisis of identity makes religious fundamentalism the most actual and controversial ideology in modern times. The claim of the universalistic religions that the world was created by a single God brings us to the conclusion that religion is one of the most important driving forces of globalization. Christianity and Islam have been shown as the most effective globalizing forces, especially due to their missionary work. This is more explicit in Islam. The worldly goal of Islam is the creation of a community of believers, in which the practices listed in the Quran will be adhered by on a consistent basis and which in the militant version will be engaged in a Holy War against unbelievers. The rapid demographic growth of Muslims is why Islam can be considered the religion of globalization. However fundamentalism is just an answer to the challenge of globalization.

From here, we ask ourselves where does the actuality of religious fundamentalism come from and what does its revitalization in the $21^{\text {st }}$ century mean? We can give two contradicting answers to this question. According to the first view, fundamentalism is an essential deviation, a symptom of adjusting to a modern and secularized culture. On the other hand, proponents of the second view see fundamentalism as a permanent phenomenon, which appears as a consequence of the failure of secularism to satisfy the need for spiritual needs and a spiritual truth. The Shia fundamentalism in Iran has created the fiercest commitment and dedication, and as such, has been used for the expression of antiwestern tendencies, by creating antipathy towards globalization as a worldly process. This was clearly evident in the Taliban regime in Afghanistan and the jihad groups (like AlQaeda) for which the spiritual search for religious basis and traditions has become a synonym for militant politics and armed conflict.

Now we ask ourselves the crucial question: what are the reasons for religious fundamentalism, which in its essence is a positive political ideology, to turn into a negative phenomenon, which relies on aggression in achieving its goals? There are a few sources that create fundamentalist militancy. Firstly those which act in the name of religion and believe their goals are ordained by God. Secondly, fundamentalism is a form of collective identity. Identity politics, no matter what kind (political, societal, ethnic or religious) have a tendency of creating an us vs. them mentality. This can result in violent behavior especially when we talk about ethnic and religious identities. Thirdly extreme fundamentalists, create a clear 
border between good and evil. In that sense 'we' are the chosen people and represent good and 'they' are sinful and the personification of evil.

\section{Religious Fundamentalism and the Conflicts in the Balkan Region}

The increased connectivity between religion, religious communities and politics are especially characteristic of the Western Balkans after the fall of socialism, when the religion and culture became the most important features of the identity of individuals and groups. The members of different ethnic groups simply felt the need of an identity that will differ from the rest. The need for belonging in a certain group and identification with said group, in the transitional period, was mostly found in religion. The ethnic conflicts on the soil of ex Yugoslavia culminated on the croato-serb-bosnian line. Among these three peoples, religions and confessions have been and are (more or less) a factor of societal integration. In those conditions national communities have implemented religious values in their system of values. This is how the road to the sacralization of a nation has been paved, and religion and confession have emphasized their integrative function and role between members from the same national community, as well as their disintegrative role towards members of other national communities. The disintegrativity has been clearly apparent in times of animosity between religions and confessions (Cvitković, 2004: 207). In these circumstances, religion plays a role of a national ideology and in this context the idea of unity of the national and confessional dominates.

With the revitalization of religion in the Western Balkans after the fall of communism, especially with the revitalization of Islam, the basic understanding and preaching of Islam changes. Unlike earlier, when the Islam of these regions seemed to accept the modern views of the world (especially in terms of secularization), now it changes its attitude. These changes in attitude were first propagated by the reis ul ulema of the most prominent Islamic community in the Balkan region- the Islamic religious community of SFRJ, Jakub Selimovski in the journal of the IRC of BiH 15.11.1991, where it is clearly stated: 'Seen from a religious aspect, nobody should be irritated by the fact that, where Muslims are the clear majority or make up $100 \%$ of the population, their religious obligation is to return to the organizing of societal relations on the basis of Islam' (Јевтић, 2009: 262). This attitude clearly shows his commitment for all the Muslims in the second Yugoslavia, there where they are the majority, to create a state based on Muslim principles, where nonmuslims would be restricted in their rights. Considering the fact that most 
Albanians the live on the territory of ex Yugoslavia are Muslims (more than 90\%) according to a large number of theoreticians on the territory of the West Balkans a process of albanization would occur, instead of a process of islamization. Experts of the field of demography think that if the current level of natality remains for the next 70 years the population of the ex Yugoslav states would be $60 \%$ Albanian. This means that sections of Serbia, Montenegro and Macedonia would practically constitute a new Albania (Јевтић, 2009: 264).

It can be said that the $1990-2000$ period was a period of radical political mobilization of the religious communities, religious beliefs and symbols for political gain for Bosnia and Herzegovina. The most prominent confessional institutions have given legitimacy to the politics that followed approximately the same ideal: one nation, one confession, one state. In this country, religious affiliation means having a series of other indicators. If, in postwar Bosnia and Herzegovina, you know of the religious affiliation of a person, you know the persons nationality as well (Bosnian, Serb, Croat) what newspapers the person reads, in what quarter the person lives or wants to live in and for which political party the person will vote for.

By analyzing Islam and its development on the Balkan Peninsula, a subtle tendency for radicalization can be noticed. Namely, from a starting point where modern interpretations and modern world views dominate, we can see devolution towards dogmatism and scripture lessons. We need to ask ourselves one crucial question, when we talk about the politicization of Islam and the existence of Islamic fundamentalism: From where does the politization of Islam starts to be implemented. The analyses show that in $\mathrm{BiH}$ the islamization of the republic started when the country gained independence, and this is primarily manifested by the implementation of scripture lessons in education, the consumption of foods by Islamic guidelines in hospitals and prisons, the banning of pornographic magazines from stores, and more importantly, the attempt to create an Islamic military power. This could be seen by the attempt of the proclamation of the Muslim National Assembly in Sandzak. The goal for this is the separation of certain parts from Serbia and Montenegro, which would be the first phase in the creation of an Islamic state in second Yugoslavia. This would be followed by a unification of Kosovo and Western Macedonia, where the Muslim population dominates. This is backed by the researches which show a large degree of religiosity in the Muslim population in the sense of a direct connection to their religious leader, which confirms that the massive participation of 
Albanians in the secessionist movement would not happen without the direct and tacit support of the IRC (Јефтић, 2009: 265-267).

Despite the existence of many religious organizations and schools in Bosnia, not a single fierce advocate for the jihad has appeared. These types of people come from Kosovo and go to Sarajevo to teach the populace what real Islam is. These teachings are most prominent in Novi Pazar, as the most Bosnian city. Their idea is that the position of Muslims cannot be bettered by the use of paper and magazines, but by the spreading of Islam everywhere and the assurance of the people that there is only Allah. Then they teach the populace to purify their hearts from all idols and to go on a Holy War - jihad if necessary. The radical islamists believe that the only way for Islam to survive is by following the three holy ideals - faith, economy and going towards Allah when the time comes - jihad (Јефтић, 2009:10-11). When we talk about fundamentalism in the Balkans we cannot skip Albania as well. The scientists who study fundamentalism, state that there have been crucial changes in Albania. As time passes Albanian Muslims transform themselves from members from the moderate Hanafi Islam (which preaches coexistence between Muslims and non-Muslims) to members of wahhabism and neowahhabism. This is especially dangerous considering the fact that we know that neowahhabism is the ideology of AlQaeda.

\section{Religious Fundamentalism and the Religious Conflicts in the Republic of Macedonia}

The tendency to preach a form of Islam with fundamentalist elements is present in the Macedonian society and this form of Islam is greatly accepted by the Albanian populace. According to our sources about 80 ethnic Albanians in R. Macedonia have been theologically educated in faculties in countries that practice radical Islam. Unlike 2010, when there was an ongoing battle for dominance between different Islamic teachings, today the theologists that were labeled as radical Islamists and wahhabists by the IFC are integrated in the same institution. Today, all theologists that have been educated in the Islamic faculties in Saudi Arabia and Turkey are hired by the IRC as priests, hatibs, librarians and teachers in public primary schools teaching Religion and ethics, which in essence constitutes scripture lessons. For these activities the IRC gets financial support from Muslim NGOs which are many in R. Macedonia and dictate the direction of the classes in public school and preaching's in the religious objects (Matevska, Matevski, 2013). 
The preaching of this type of Islam, which contains a large dose of political impurities, to the Albanian believers can increase nationalism, can convince the believers that they are marginalized in the frame of the Macedonian society, and to mobilize them to do a certain societal action. This type of nationalism, with certain chauvinistic elements from the side of the Albanian ethnic group, is already noticeable in R. Macedonia. The intolerance in relation to ethnic and religious affiliation culminates into frequent violence on an ethnic level in the younger population. In environments where the Albanian ethnic group is the majority (northwestern and western Macedonia) the disrespect towards the legal state is noticeable, the disrespect towards national symbols (the burning of the Macedonian flag, emphasizing of only the Albanian flag in front of state institutions), Albanian mayors 'forgetting' to erect the Macedonian flag during state holidays, 'ethnic cleansing' of the Macedonians employed in the local government etc. If you add the demographic growth of Albanians, which is the highest of all ethnic groups in Europe, and the similar problem that the Serbs in Kosovo faced during the 70s, it can be concluded that these events aren't random, but are connected to a well structured agenda and strategy. The intention is to create an ethnically pure territory in the cities that already have Albanian mayors and are dominated by the Albanian population (Tetovo, Gostivar, Kichevo, Struga, and Debar). These previously mentioned actions create a feeling of insecurity in the Macedonian minority and are done with the intention to make the populace leave the places they called home for generations. This strategy was proven successful in Kosovo, so there is no reason for this to not work in R. Macedonia.

In addition to this thesis is the statement of the leader of the IRC ahead of the celebration of the 100 anniversary of the independence of Albania and the Albanian flag in November 2012. In an interview in the paper 'Journal Plus': "The unification of the Albanian countries is the will of God, which is why we have an obligation to return them to what they were. The unification of the powers of the Albanian people on all levels will become a reality, and Albania will have a single border, created by God. The IRC is prepared to contribute, with all its capacity, to the national cause and answer any call towards the unification of all Albanians. We can't live in 5 countries; it is unacceptable for you to leave here, your father in your homeland, and your brothers outside of the borders..."

According to the analysts, this kind of statement is irresponsible and inappropriate and is a classic attempt of manipulation of religious feelings. This rhetoric is especially dangerous and leads to a deeper divide between the Macedonians and Albanians in Macedonian society, and stirs ethical extremism and separatism, which were already 
strengthened in the Albanian population in R. Macedonia after the separation of Kosovo and its self proclamation as an independent country.

When it talks about radical Islamic structures in R. Macedonia, the IRC thinks of Islamic theologists who have finished their theological education in universities in countries that practice and preach radical Islam. During socialism, Islamic theologists were educated in faculties in countries like Syria and Egypt, which are closer to the Muslim tradition practiced in ex SFRJ. After the independence of R. Macedonia, the Islamic theologists started to educate themselves in Islamic faculties in Saudi Arabia (Mecca, Medina, Rijad), where radical Islam is practiced. According to our sources around 80 ethnic Albanians form R. Macedonia were educated in faculties from countries where radical Islam is practiced.

Unlike 2010 when the Islamic corpus fought a battle to determine which Islamic teaching will be preached and practiced in R. Macedonia, and who will lead the IRC today, all theologists that were labeled as radical isslamists and wahhabists are integrated in the frames of this institution. The integration of these theologists started in 2012 and today this process is finished, with which, all theologists who have been educated in Islamic faculties in Saudi Arabia and Turkey, are hired by the IRC as priests, hatibs, librarians and teachers in public primary schools for the subject Religion and ethics, which in essence is a set of scripture lessons (Matevska, 2013).

Which form of Islam will dominate in R. Macedonia? Will it be the radical or traditional current? Only time will tell. The fact remains that the IRC act as priests and teachers in public schools that practice diametrically different Islam at the same time: a traditional Islam that is native to the region and a fundamentalist Islam imported from Saudi Arabia. Religious fundamentalism is often manifested as a partial or complete disregard for modern ideas, whether it is religious tolerance, secularization, different accomplishments in science and technology which for one reason or another aren't compatible to the religious doctrine. This is why, according to many scientists, Islam is often connected to nationalism. (Matevski, 2013).

\section{Conclusion}

Islam has never been just a religion. It is a complex way of life with detailed instructions for the moral, economic and political actions of individuals and societal groups. The crucial feature of Islamic fundamentalism is the idea that the Islamic religious principles should be the main principles of the societal, moral and political life of a country. 
This is where the intention for religion to take primacy over politics comes from. In practice, this means that an 'Islamic state' should be established on theocratic principles, instead of a secular state where religion is separated from politics. In a theocratic country there is overlap between religion and politics. Here the spiritual authority rules over worldly authority with theocratic principles as a codex of legal and moral behavior, with a system of punishment for anyone who breaks Sheria law.

The process of secularization is greatly obstructed by the Islamic religious tradition in which the worldly and spiritual are tightly connected. In these countries the wave of secularization couldn't permeate more, so the religious community is still a considerable power in the societal and political life. Sociologists today, state the return of religion, taking religion and confession as factors of identity, instrumentalization of religion and confession in politics, greater presence of religions and confessions in mass media as social indicators for slowdown of the secularization in post socialistic states. This pushes the idea of post secularism, or the return of religion.

Will the radical or traditional Muslim current prevail? Only time will tell. The fact remains that the members of the IRC acts as priests, teachers in public schools, theologists who practice diametrically different Islam: a traditional who is native to the region and a radical, fundamentalist Islam imported from Saudi Arabia. The large number of theologists that preach radical Islam in Muslim religious objects and public educational institutions, and the fact that no one has control over who preaches to believers and who teaches minors in terms of primary public education, presents a serious threat to the ethnic and religious tolerance, and the peace and stability in R. Macedonia. This is done by fundamentalist Islam by pointing towards the pointing out the differences which are often connected to nationalism. Religious fundamentalism is often manifested as a partial or full rejection of modern ideas, whether it is religious tolerance, secularization, different advancements in science and technology, which for one reason or another are not compatible with religious doctrine. This is why, according to many scientists, Islam is often connected to nationalism.

\section{References}

1. Cvitkovic, Ivan. 2004. Sociologija religije. Sarajevo: Des.

2. Davie, Grace . 2013. The Sociology of Religion: A critical Agenda. London: Sage publications $L T D$. 


\section{Securilatity}

3. Hejvud, Endru .2005. Političke Ideologije. Beograd: Zavod za uđbenike i nastavna sredstva

4. Јевтић Мирољуб . 2009. Политикологија религије. Београд: Центар за проучавање религије и верску толеранцију

5. 2001. Савремени џихад као рат. Београд: Никола Пашић

6. Matevska, Dushka i Matevski, Zoran. 2013. National and Religious Identity in R. Macedonia in Global Age. Kosovska Mitrovica: Faculty of Philosophy, University of Pristina.

7. Matevski, Zoran i Matevska, Dushka. 2012. The culture of peace as a precondition of the Euro-Atlantic perspectives of the Balkan region. In Proceedings from the International scientific conference: Security and Euroatlantic Perspectives of the Balkans. Ohrid: University St. Kliment Ohridski.

8. McGuire, Meredith. 2002. Religion - the social context. USA: Wadsworth Thomson learning 